\title{
先天性多発性関節拘縮症（AMC）の下肢変形について
}

\author{
福岡市立こども病院・感染症センター整形外科 \\ 太田剛・藤 井敏男 \\ 井上敏 生 - 高 嶋 明彦 \\ 九州大学医学部整形外科 \\ 大 石 年 秀 \\ 別府整肢園整形外科 \\ 佐 竹孝之
}

\section{Contracture of the Lower Extremity in Arthrogryposis Multiplex Congenita}

by

\author{
Tsuyoshi Ohta, Toshio Fujii, Toshio Inoue \\ and Akihiko Takashima \\ Department of Orthopedic Surgery, \\ Fukuoka Children's Hospital \\ Toshihide Oishi \\ Department of Orthopedic Surgery, \\ Kyushu University \\ Takayuki Satake \\ Beppu Seishien, Hospital for the Crippled Children
}

We studied 61 patients with Arthrogryposis Multiplex Congenita during the period of 1926 to 1990. Joint contractures of the lower extremity at first visit were reviewed.

Of 122 extremities; 98 foot deformities, 84 knee contractures and 63 hip contractures (40 dislocations and 23 contractures only) were seen showing the frequency of joint contractures to be higher distally than proximally.

The main cause of the gait disturbances are multiple joint contractures. The combination of hip dislocation-knee extension contrature (dislocation)-pes equinovarus is the most important factor in the development of the gait disturbance.

\section{はじめに}

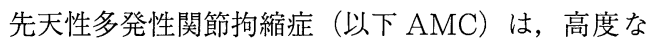
関節変形と拘縮のため治療に難渋する事が多い。今回 我々はその下肢変形の病態を明らかにする目的で調査 を行なった。

\section{対象及び方法}

1929 年から 1990 年までに福岡市立こども病院, 九 州大学整形外科及び別府整肢園における症例は 61 例
(男 32 例，女 29 例）である。年令は平均 3 才，最長 40 才であった.

これら症例の初診時における股, 膝, 足関節個々の 罹患頻度及び変形の種類を調査し，3つの関節の变形 の組合せに対し検討を加えた。また歩行機能との関係 を検討した。

結

果

股関節の変形は全症例 61 例 122 肢中脱臼 40 股，脱 臼を伴わない関節拘縮 23 股を認めた。またその内訳 


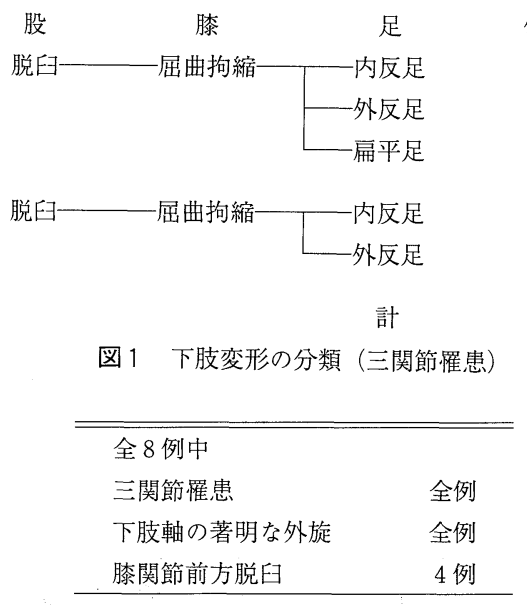

図 2 歩行不能例（ 4 才時）

は対称性䍜患 29 例，片側性 5 例，計 34 例（56\%）で あった。

膝関節は 41 膝に伸展拘縮， 43 膝に屈曲拘縮を認め, 同時に 12 膝に前方脱臼, 反張膝, 動摇性等が存在し た。また対称性罹患 38 例，非対称性罹患 1 例，片側 性 6 例の計 45 例（74\%）であった。

足関節及び足部変形は 67 例と半数以上に内反足変 形を認め, さらに尖足 8 足, 外反足 19 足, 垂直距骨 による扁平足変形 4 足を認めた。また対称性罹患は 48 例, 片側性 2 例, 計 50 例（82\%）であった.

股，滕，足関節の関節变形の組合せを分類してみる と三関節とも罹患している症例は 21 例あり，股関節 脱臼一膝伸展拘縮一内反足の組合せが 9 例で最も多く, 次いで股関節脱臼一膝屈曲拘縮一内反足が 5 例，股関 節脱臼一膝屈曲拘縮一外反足 4 例の順であった（図 1). また単関節のみの罹患例が 16 例あったが，股関節の みの症例はなく，膝関節 5 例，足関節 11 例であった (表 1).

最後に歩行機能との関係を検討すると，4才時に歩 行不能であった症例が 8 例存在した（図 2 )。それら の症例は全例三関節罹患例であり，著明な下肢軸の外 旋を有していた。

\section{考察}

AMC の特徴としては一般に四肢の複雑関節に拘縮 があり，拘縮は中枢側より末梢側に多く，対称性であ る. 代表的な変形は股屈曲外旋, 膝屈曲拘縮・膝反張,
表 1 下肢变形の分類（単関節罹患）

\begin{tabular}{c|c}
\hline \hline 関 節 & 例 数 \\
\hline 股のみ & なし \\
\hline 膝のみ & 5 \\
\hline 足のみ & 11
\end{tabular}

表 2 文献上の関節羅患の頻度

\begin{tabular}{c|c|c|c|c}
\hline \hline & $\begin{array}{c}\text { Friedlander } \\
(1968)\end{array}$ & $\begin{array}{c}\text { Hahn } \\
(1985)\end{array}$ & $\begin{array}{c}\text { Carlson 5 } \\
(1985)\end{array}$ & $\begin{array}{c}\text { 自験例 } \\
(1990)\end{array}$ \\
\hline 症例数 & 45 & 96 & 52 & 61 \\
\hline 股関節 & $82 \%$ & $43 \%$ & $56 \%$ & $56 \%$ \\
\hline 膝関節 & $87 \%$ & $54 \%$ & $71 \%$ & $74 \%$ \\
\hline 足関節 & $91 \%$ & $80 \%$ & $85 \%$ & $82 \%$ \\
\hline
\end{tabular}

内反足である. 当科の症例においても他の報告と同様, 左右の対称性罹患が多く，末梢関節ほど罹患頻度が高 かった ${ }^{122) 4}$ (表 2 ). 三関節罹患例では股関節脱臼一 膝屈曲拘縮又は伸展拘縮一内反足の組合せが 14 例と 過半数を占めた．また下肢の単関節䍜患例を 16 例認 めたが，これらの症例は上肢の関節䍜患により診断さ れたもので，下肢変形に関しては比較的評価を行ない やすい．実際に臨床の場で最も問題になるのは多関節 罹患例であるが，今回の調査において 4 才時に歩行不 能であった症例は，全例，三関節罹患例であり，全例 とも下肢軸の著明な外旋を有していた ${ }^{3)}$.これらの症 例は個々の関節変形が高度であると同時に，股関節の 拘縮及び膝関節の変形のため正確な alignment が把 握しにくく，そのため正確な変形の矯正が困難である と思われる。従って適切な治療のためには関節造影な どによる下肢軸の正確な把握が重要であると思われた。

\section{参 考 文 献}

1) Friedlander, H. L., et al.: Arthrogryposis Multiplex Congenita. A Review of forty-five cases. J.Bone and Joint Surg., 50-A : 89-112, 1968.

2) Geroge Hahn.: Arthrogryposis: Pediatric Review and Habilitative Aspects. Clin. Orthop., $194: 104-$ 114, 1985.

3）大石年秀, 藤井敏男, 野村茂治, 他：Arthrogryposis Multiplex Congenitaの下肢変形について. 中部整災誌, $22: 52-55,1979$

4) Walter O. Carlson, et al.: Arthrogryposis Multiplex Congenita: A Long-term Follow-up Study. Clin. Orthop., 194 : 115-123, 1985. 